\begin{tabular}{|c|c|c|c|c|c|}
\hline 疤荫 & 例数 & 第一型 & 第二型 & 第三型 & 繌計 \\
\hline 急性中耳炎 & 8 & 0.38 & 22.64 & 39.25 & 62.25 \\
\hline 慢性中耳炎 & 9 & 0.56 & 17.28 & 42.11 & 59.94 \\
\hline 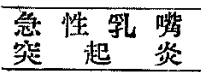 & 13 & 0.23 & 28.81 & 47.67 & 77.50 \\
\hline 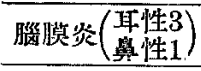 & 4 & 0.75 & 15.25 & 28.87 & 44.87 \\
\hline 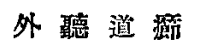 & 5 & 0.33 & 27.33 & 33.0 & 60.66 \\
\hline 慢性副燢窥炎 & 16 & 0.34 & 15.47 & 34.0 & 49.81 \\
\hline 节 & 4 & 1.0 & 23.0 & 32.0 & 56.0 \\
\hline 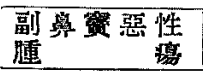 & 5 & 2.8 & 24.6 & 68.2 & 95.6 \\
\hline 懁桃腺炎 & 5 & 1.33 & 24.0 & 34.0 & 59.33 \\
\hline 急 㘪腺炎 & 5 & 0.4 & 19.9 & 37.7 & 58.0 \\
\hline 急性咽喉䪽炎 & 4 & 0.66 & 22.33 & 36.83 & 59.83 \\
\hline$\gamma \approx ゙ / 1 ト$ & 4 & 1.12 & 23.37 & 38.37 & 62.87 \\
\hline 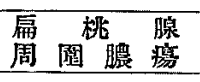 & 3 & 1.33 & 27.0 & 40.67 & 69.0 \\
\hline 呢 頭 癌 & 3 & 0.66 & 23.66 & 50.0 & 74.38 \\
\hline 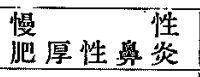 & 3 & 0.5 & 26.33 & 43.0 & 69.83 \\
\hline 㓩溲性學炎 & 4 & 0.5 & 17.37 & 38.12 & 55.75 \\
\hline 正第 人 & 20 & 0.7 & 19.8 & 42.45 & 62.95 \\
\hline
\end{tabular}

即チ，耳疾㭧中．中耳炎＝於テハ略を，正常值 ト同檬デアルガ. 乳嘴突起炎二於テハ血小板ハ 增加ス。而シテ第 2 型二於テ甚ダシ。畠膜炎= 於テハ逆二減小ス。鼻疾患二於テ慢性ノ蓄膿症 二於テ八稍 3 減少ス。惡性腫瘍二於テ八选ダシ ク增加ス。第 3 型二於亏殊二然り。尚木第 1 型 モ增加ス。扇桃腺疾腎二於テ八大體正常值中二 アルモ. 2-3 第 1 型ノ稍 2 燴加スルガ如シ。 倘示余八耳性敗血症其他 2-3，疾患八例數不 足ノ䉆メ報告シ得ナカッタガ. 更二次回終報卜 シデ完全ヨ期サウト思ツテキル。

\section{類題 耳疾患二於々ル血小板}

消長卜其診斷的價值二就テ

筑 紫 檾一(東 京)
血小板ガ血液，第 3 要素トシテ重要ナコトハ 諸賢ノ御承知ノ事デアリ 之ガ检索习行ヒ。抙

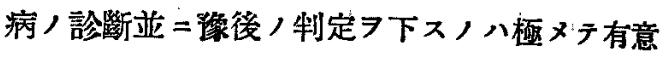
䉝ノ事卜思ヒマス。私八耳疾患コト＝中耳疾㭧 及ビ其合係症ニシキ此检查ヨ行ヒアシタノデ其

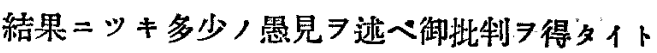
思ヒマス。

血小板检查八其性質上從來八カナり困難トサ レ.箎二種タノ檢查方法ガ考案サレテ居マスガ.

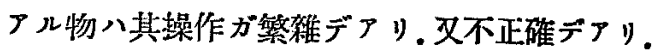
或物八設借 $=$ 費用 7 要ス几篇入實際=臨牃的 $=$ 之ラ應用スルニ不便フ感ジタノデアリマス。私 八此點カラ松岡一川畑氏法ガ適當デアルト考へ マシタノデ本法ア探用致シマシタ。简單 =其方

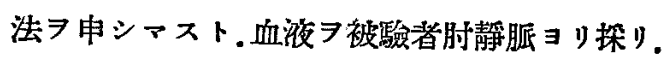
同時 $=$ 之 7 血液凝固防止劑夕ル第 1 液卜混和稀 釋シ. 之ヨ赤血球算定用「ピベット」=吸引.

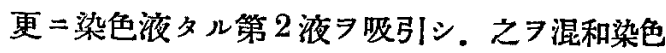
シ一定時啳=血球計算室 =封入計算スルノデヌ リマス。

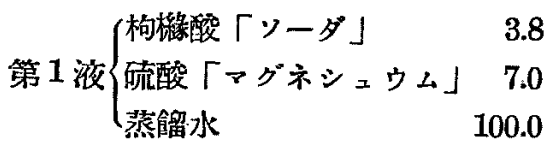

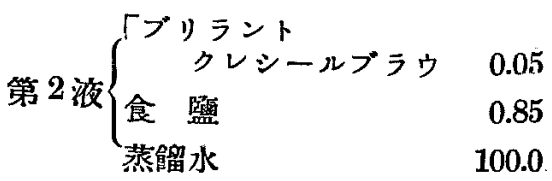

デアリマス。

私ハ先ヅ 10 名ノ健康者ニッキ检查政シャシタ (表示)。

向木諸家ノ算出シマシタ正常血小板ト併七考へ マスト大體 30 萭前後ヨ以テ正常ト見テョイ ト思ヒマス。

次ニ私ノ检查シタ處ノ結果ニッキ說明致シャ 


\section{z.}

本檢查ニハ患者”俰件 テナルベク一定ニスルト イフ考へノ下二最モ都合ノヨイ時刻ヨ定メテ行 ヒマシタ(表ニツイテ說明)。

先ヴ急性中耳炎，場合二於テ八（14 例）其本均 數八正常數ヨリ秒?增加シテ居リマスガ大顝發 病日二近イモ/程其數モ少イ樣こ思ハレマシ 夕。

更二乳嘴㐐起炎 7 合作シタモノンツイテハ (15 例) 平均大體正常數，筑圍ニアリマスガ. 急性 中耳炎, 平均值ヨリ少イ樣デアリマス。向ホ 1 例ノ 40 葻以上ノモノニ於デ八手術习要セズシ テ治硚シテォリマス。

静胍管疾患 $\ni$ 合阙シタ場合二於テハ其合併掟何 レモ乳嘴突起炎ノ場合ヨリモ明カ二減ジテオリ マスガ. 合侏症，重篤トナルニツレテ減少シテ オリマス。

此場合內頸滕脈 $タ$ 結栤シマスト熟レモ急激二血 小板ノ增加 $尹$ 來タシマス( 3 例圆示)。敦レモ軲

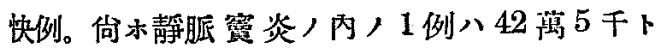
イフ增加ヨ示シテキルモノガアリマシタガ.十 ハリ内頸靜脈結森 $=ヨ$ 急激二夫レ以上＝㙞加 シ. 次第二正常ニ歸ツテュキマシタ。

1934年 Hesse，靜脈露血栓二於ケル血小板， 診斷的價值ニツイテ述ベテ居リマスガ. 私ノ結

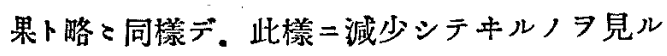
卜血小板ノ检查八本合件症ニ於テカナり重要ナ 臨㸛的價值がアルト思ヒマス。 耳性腦膜炎/場合ニ八多少娍少ノ傾向アリ症 狀ノ惡化スルニッレテ減少シテ居リマス。

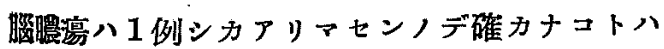
ワカリマセンガ著明二增加シテ居りマス（白血 球八略了血小板數二逆比スル)。
倘ホ手術ニシル影響习見マスト大多數ノモノ八 手術後一時血小板減少 過良好，場合二八增㸝シ4-13日一14日後=八 其極值二達シ次第二減少シテ後正常ニカヘッテ オリマス。份ホ不良,經過ヨトル場合 (Sinus

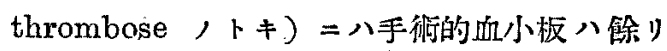
篔加セズ。

結諭

以上各症例二於ケル血小板ノ消長ア見アスト。 血小板八特二靜脈蜜血栓及ビ之ョリ生ズル敗血

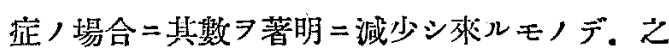
ヨ以テ靜脈窑血栓及ビ耳性敗血症誈断, 補助卜 ナシ得ベキモノト考へマス。 向ホスベテノ場合症状，惡化ズルンレテ血小 板八減少 加シマス。殊＝靜脈䆬血柽ノ場合內頸靜脈 $シ$ 結 禁シタ後血小板，增加ス儿場合八總亏辣後良好 ト考ヘラレマス。即チ此場合血小炍检查八函後 ノ制定ノ上ニモ重要ナ役割 アリアス。

\section{6. 慢性「モルヒネ」中毒者二於}

\section{ケル聽器臨牀所見}

韓 基 澤(京 城
北

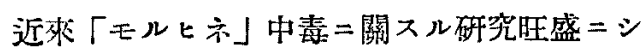
テ. 先賢諸氏ノ柴續中二八機多，學理明究サレ タリト云へドモ耳鼻咽喉科方面ノ研究八極メテ 察タタリ。

余等八京城帝大久保神經，精神科二入院七ル慢 性「モルヒネ」類中毒者 31 名二就テ聽器機能 フ檢測スル機會ヨ得タルラ以テそラ簡單=赫告 セントス。

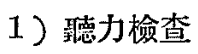

